\begin{tabular}{|c|c|c|c|}
\hline $\begin{array}{c}\text { Travaux du Muséum National d'Histoire Naturelle } \\
\text { «Grigore Antipa» }\end{array}$ & Vol. LIII & pp. 287-302 & $\begin{array}{c}\text { (C) Décembre } \\
2010\end{array}$ \\
\hline
\end{tabular}

DOI: $10.2478 / \mathrm{v} 10191-010-0020-9$

\title{
BIRD FAUNA LONG-TERM MONITORING IN THE ROMANIAN LOWER PRUT RIVER BASIN
}

\author{
CARMEN GACHE
}

\begin{abstract}
In the present paper, we give data on the bird' fauna's dynamic during the last 18 years in the Romanian Lower Prut River basin. This valley shelters a good level of the biodiversity being very well protected through the border status, but due the low level of the industrial development, too, despite an increasing of the human pressure in the last years. We recorded in this area some very rare breeding bird species for Romania - Platalea leucorodia, Plegadis falcinellus, Limosa limosa, Recurvirostra avosetta, Himantopus himantopus, Luscinia svecica, etc. but also some globally threatened species like Phalacrocorax pygmeus, Aythya nyroca or Crex crex. In this sector of the Prut River basin three Important Birds Areas (IBA) were delimited, all included in the "Romanian Nature 2000 Network".

Résumé. Dans ce travail, nous donnons des informations sur la dynamique de l'avifaune dans le secteur roumain du bassin de la rivière Prut au cours des 18 dernières années. Cette vallée abrite un bon niveau de la biodiversité étant très bien protégés par le statut des frontières, mais en raison du faible niveau de développement industriel, aussi, en dépit d'une augmentation de la pression de l'homme dans les dernières années. Nous avons enregistré dans ce territoire quelques très rares espèces d'oiseaux nicheurs pour la Roumanie - Platalea leucorodia, Plegadis falcinellus, Limosa limosa, Recurvirostra avosetta, Himantopus himantopus, Luscinia svecica, etc. mais aussi des espèces mondialement menacées comme Phalacrocorax pygmeus, Aythya nyroca ou Crex crex. Dans ce secteur du bassin de la rivière Prut, trois Zones de Protection Spéciale Avifaunique (ZPSA) ont été délimité, toutes inclus dans le "Réseau roumaine Natura 2000".
\end{abstract}

Key words: monitoring, birds, breeding species, SPA (Special Protection Area), lower Prut River basin, Romania.

\section{INTRODUCTION}

The Prut River valley has a length about $742 \mathrm{~km}$ on the Romanian territory, representing a natural border between Romania and Ukraine, respectively, Republic of Moldova.

The lower basin begin in the point of the confluence between the Prut River and its principal tributary river, Jijia, near Gorban village (Iași county), while the confluence with the Danube is near Galați city (Galati county). In this sector, the Prut River receives just the waters of some rivulets, with temporary courses and two small tributary rivers, Elan and Chineja. There were done some important hydrotechnical arrangements in order to decrease the flooding risks, resulting some fisheries (Cârja - Mața - Rădeanu, Oancea, Vlădești) and one of the most important hydro-technical work in the eastern part of Romania, reducing the surface of Brates Lake to one third from initial surface.

The climate is temperate-continental, with very dry and hot summers, respectively, dry and cold winters. Normally, the rainfalls present values about 600 $\mathrm{mm} /$ yearly; in the last five years, in this sector we recorded very strong dry periods but also two high flood events, in 2006 and in 2008, both during the last decade of July - beginning of August, the last representing the historical level of the Prut River's flows. Despite the control of the waters' flow through the dam Stânca - 
Costești, in 2008, a flow level of $850 \mathrm{~m} / \mathrm{s}$ was recorded in the hydrological point Stânca, at least for 72 hours. These water level's oscillations have a great influence on the presence or absence of some natural small swamps and marshes areas in the lower part of Prut River basin, so on the vegetation and bird fauna's presence, too.

The Prut River basin is one of the poorest regions from Romania, representing the poorest area of the European Union, too (especially, in the North-eastern sector). But we must notice that, this territory still shelters a really high level of biodiversity, generally and of the bird fauna's diversity, especially, nor only due the border status that permitted just a strictly checked presence of the people (local community, fishermen), but also due the low level of industrial development of the area excepting the hydro-technical arrangements done in the sixty years of the last century, for decades, the principal activities in the area being the agriculture, grazing, fisheries activities and, only occasionally till now, hunting games.

In the lower Prut River basin, three Important Bird Areas were identified and established (Gache, 2002; Papp \& Fântână, 2008): Cârja - Mața - Rădeanu ponds and Roșcani Forest, Prut River valley (Vlădești ponds - Frumușița) and Brateș Lake (the last two are belonging to the "Lower Meadow of Prut River" Natural Park), being included in the "Romanian Nature 2000 Network" (HG 1284/2007), while the sector Mața - Rădeanu is, also, part of the mentioned natural park. Two important ornithological studies were done in this territory in the last years, focused on the terns', respectively, herons' ecology and behaviour (Cazacu, 2007; Ignat, 2009).

\section{MATERIAL AND METHODS}

During the last 18 years (1992-2009), we visited the whole Romanian territory of the Prut River basin several times and covering more than 65 observatory stations following different aspects of the birds' fauna diversity, on the qualitative and quantitative dynamic of the avifauna in the area, paying a special attention to the breeding populations. We visited the area during the all ecological seasons, using the transect method, the band counting, the fixed point observations and the nocturnal recording for some bird species. Within all this study period, we observed the influence of different human activities on the ecosystems and biodiversity, too, while in the last years, we focused our attention on the impact of the climate evolution (very strong drought in 2007, impressive flooding phenomenon in 2006 and 2008 summers, practically in the same territory) on the bird presence and bird populations trend in this territory.

In the present paper, we are focusing our attention on the lower part of the Romanian Prut River basin, analysing the field data collected from the following observatory stations: Gura Văii Swamp, Fălciu Swamps, Rânzești Swamps, Cârja Mața - Rădeanu ponds, Pochina Swamp, Şovârca Swamp, Vlădești ponds, the Prut River valley between Vlădești village and Giurgiulești crossing-border point (Vlășcuța Swamp, Cotu Chiului ponds, meadow woodlands), Brateș Lake and fishery (Fig. 1). The tributary rivers have temporary courses and small lengths. The reed beds cover large surfaces in the Cârja and Vlădești areas. The humid meadows appear during the springs with high rainfalls. The woodlands are smaller than on the left side of the basin and the inside access is very difficult due the large marshes and swampy nearest areas.

\section{RESULTS AND DISCUSSIONS}

In the whole basin of the Prut River, we recorded 250 bird species (about $66 \%$ from the Romanian bird fauna), belonging to 42 families and 12 orders (Sibley \& Ahlquist, 1990); between these, we must notice the presence of 56 bird species included in the Romanian Red Book of Vertebrates (Botnariuc \& Tatole, 2005). 


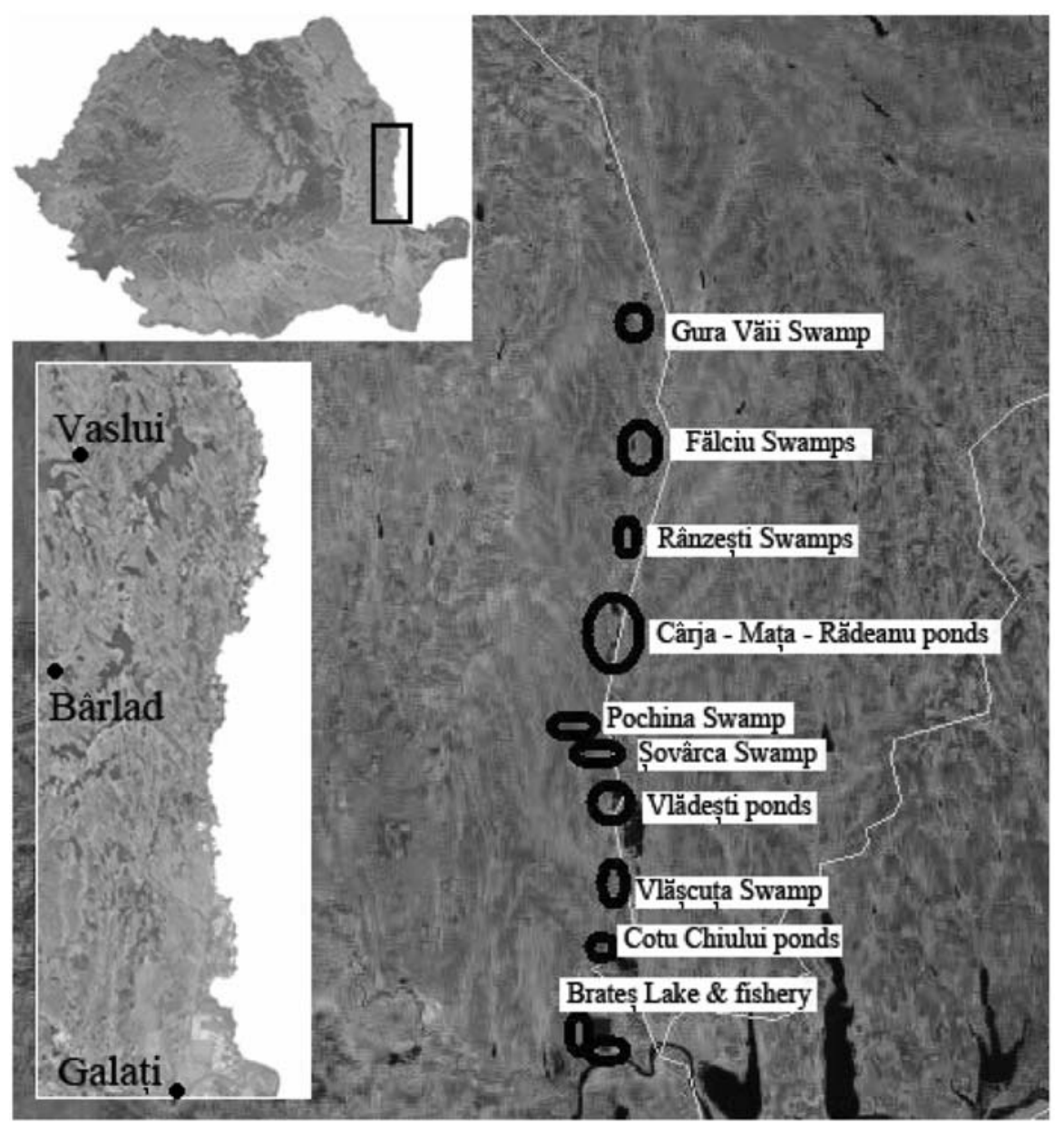

Fig. 1 - The observatory stations in the Lower Prut River basin (adapted from Geology.com, 2006).

In the lower sector of the Prut River basin, the bird fauna list include 218 species (Tab. 1), some of them met just one or twice during our study period (Netta rufina, Circus cyaneus, C. macrourus, Calidris canutus, Numenius tenuirostris, Sterna nilotica, S. caspia, Nucifraga caryocatactes), while 151 bird species are breeding or irregularly breeding in this territory, some of them being rare or very rare breeding species in Romania (Platalea leucorodia, Plegadis falcinellus, Limosa limosa, Recurvirostra avosetta, Himantopus himantopus, Luscinia svecica, etc.).

We notice an increasing of the bird diversity, including the incidentally or erratic species appearance in the last years of our study; it is possible that the wetland habitat losing and an increasing of the human interventions in the nearest areas forced the birds to search new sites for refuge, feeding or breeding, too. We have data about strong pressure on the left side of the Lower Prut River basin (infrastructure development, including a new railway building, the illegal activity of some sand, gravel and limestone quarries, the electrical fishing practice, etc.) that could produced big damages in the local ecosystems, disturbing the whole fauna, including the bird species that tried to find new sites for refuge, feeding or breeding. 


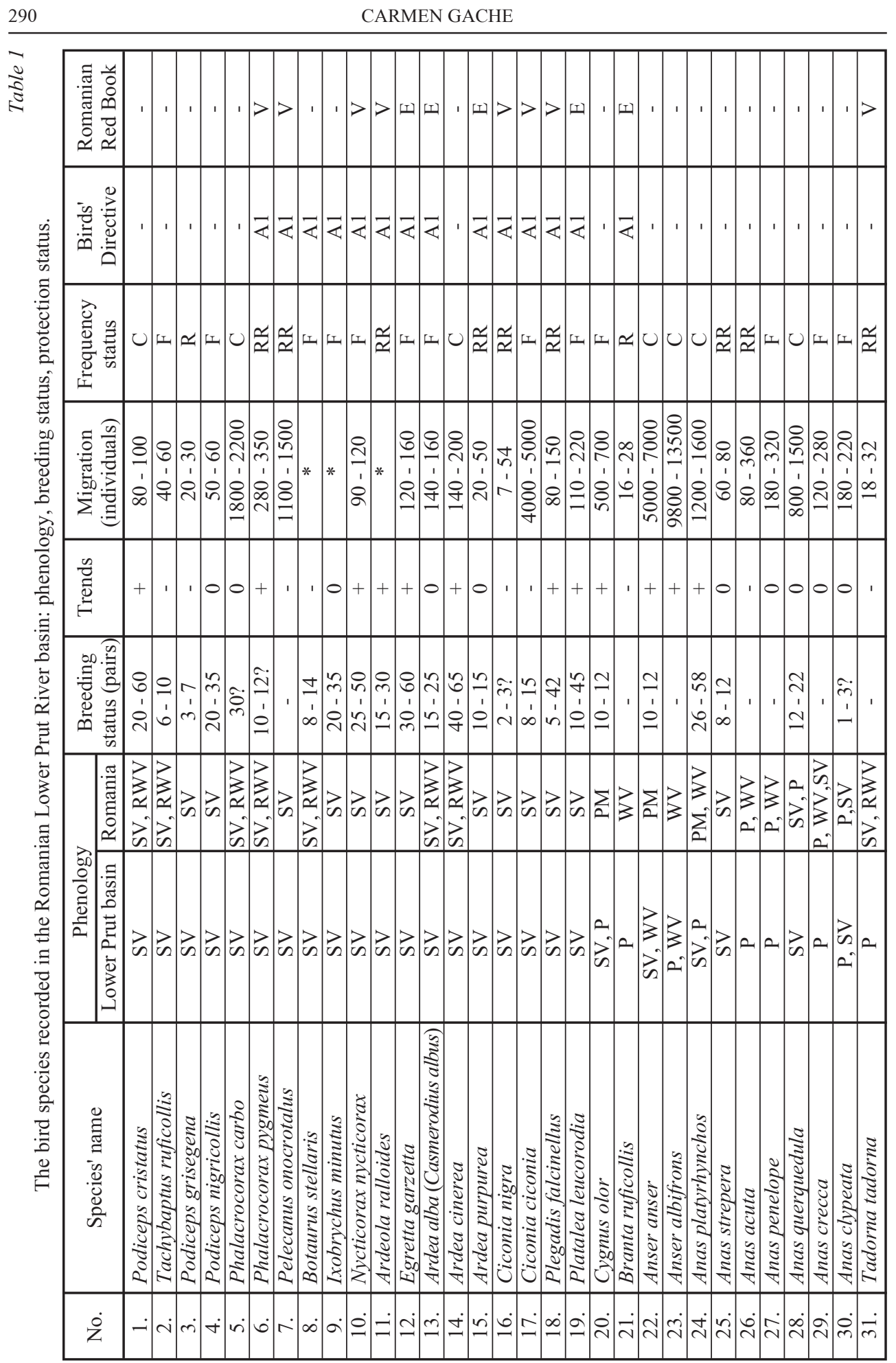


BIRD FAUNA LONG-TERM MONITORING IN THE ROMANIAN LOWER PRUT RIVER BASIN 291

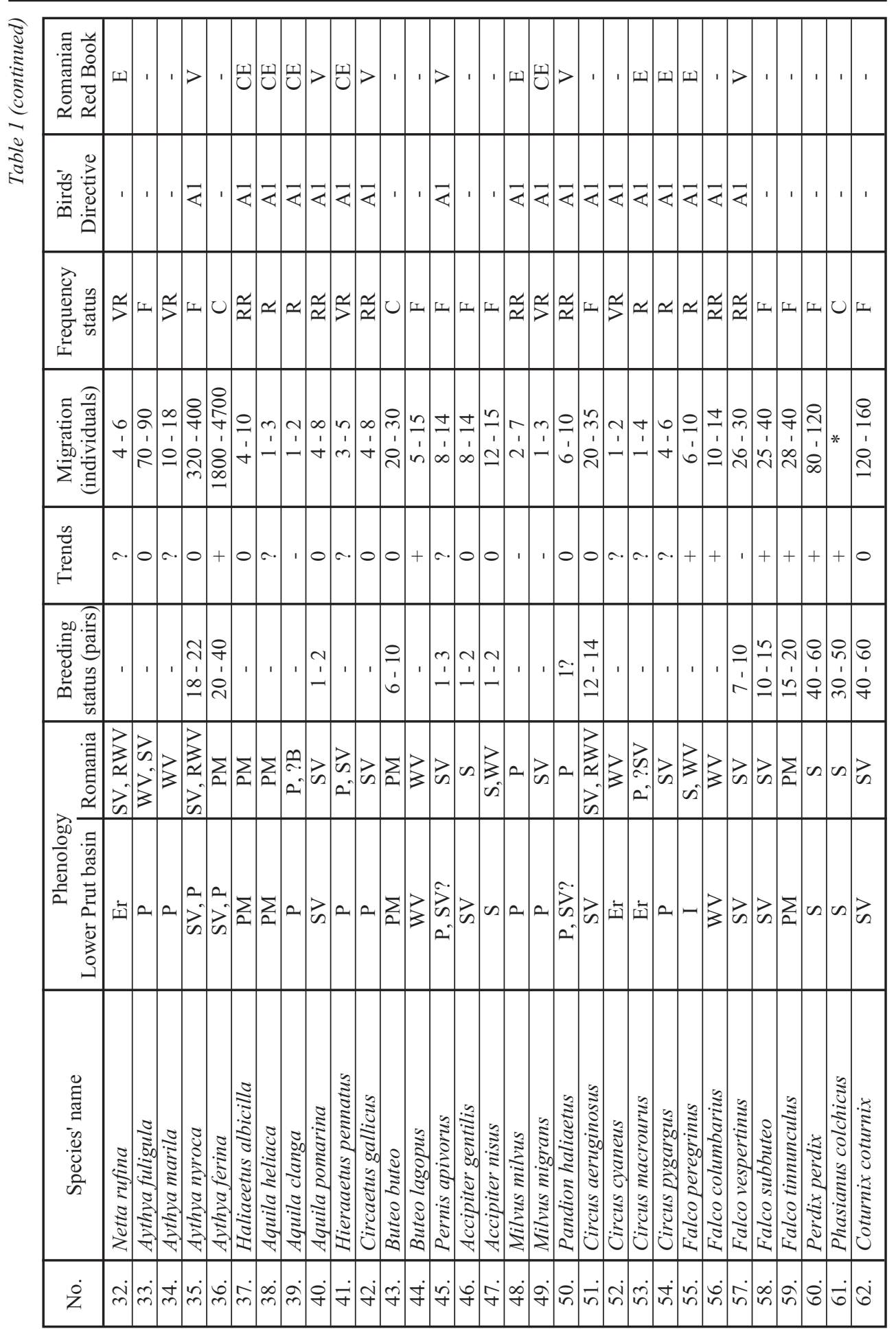




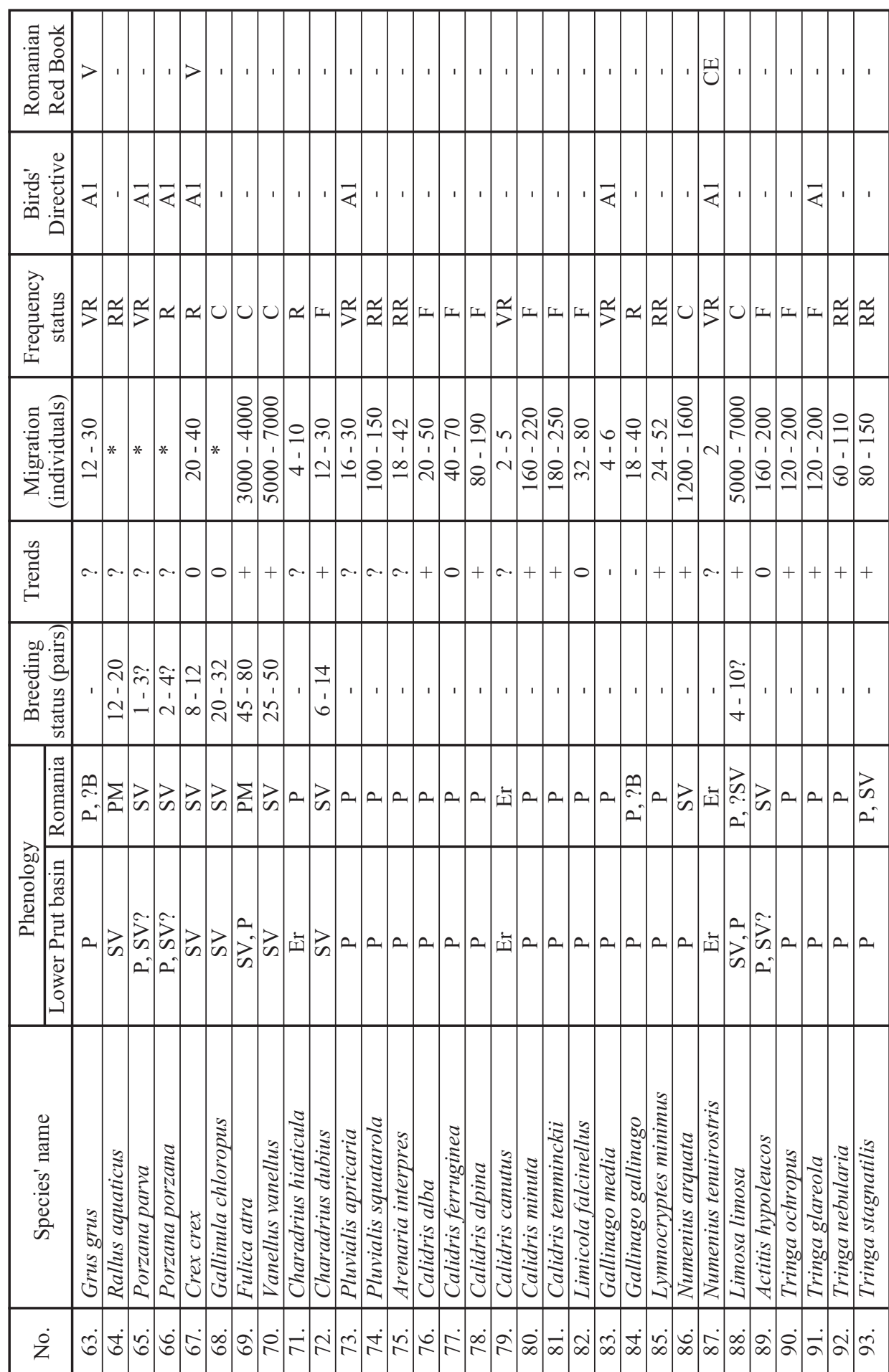


BIRD FAUNA LONG-TERM MONITORING IN THE ROMANIAN LOWER PRUT RIVER BASIN 293

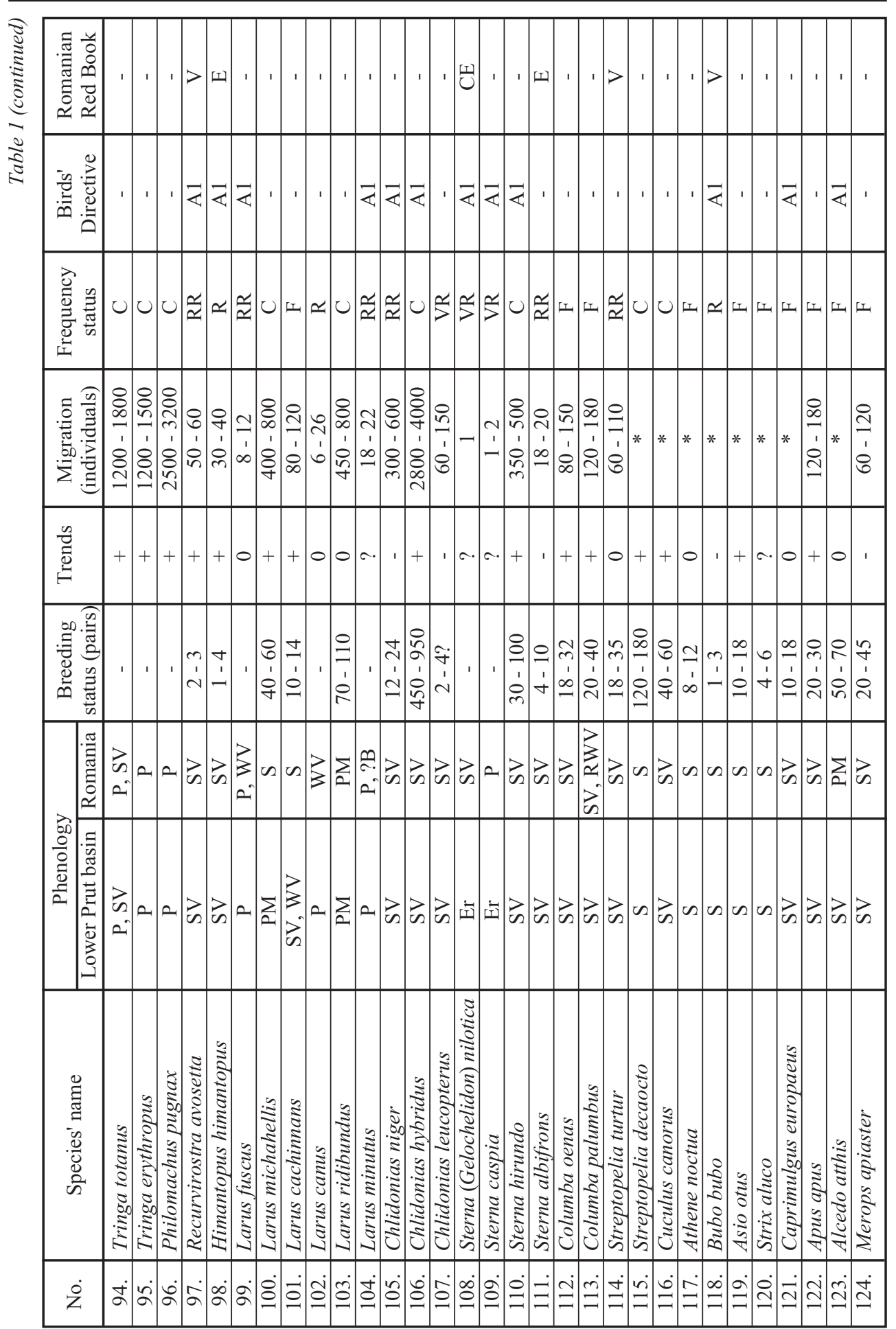




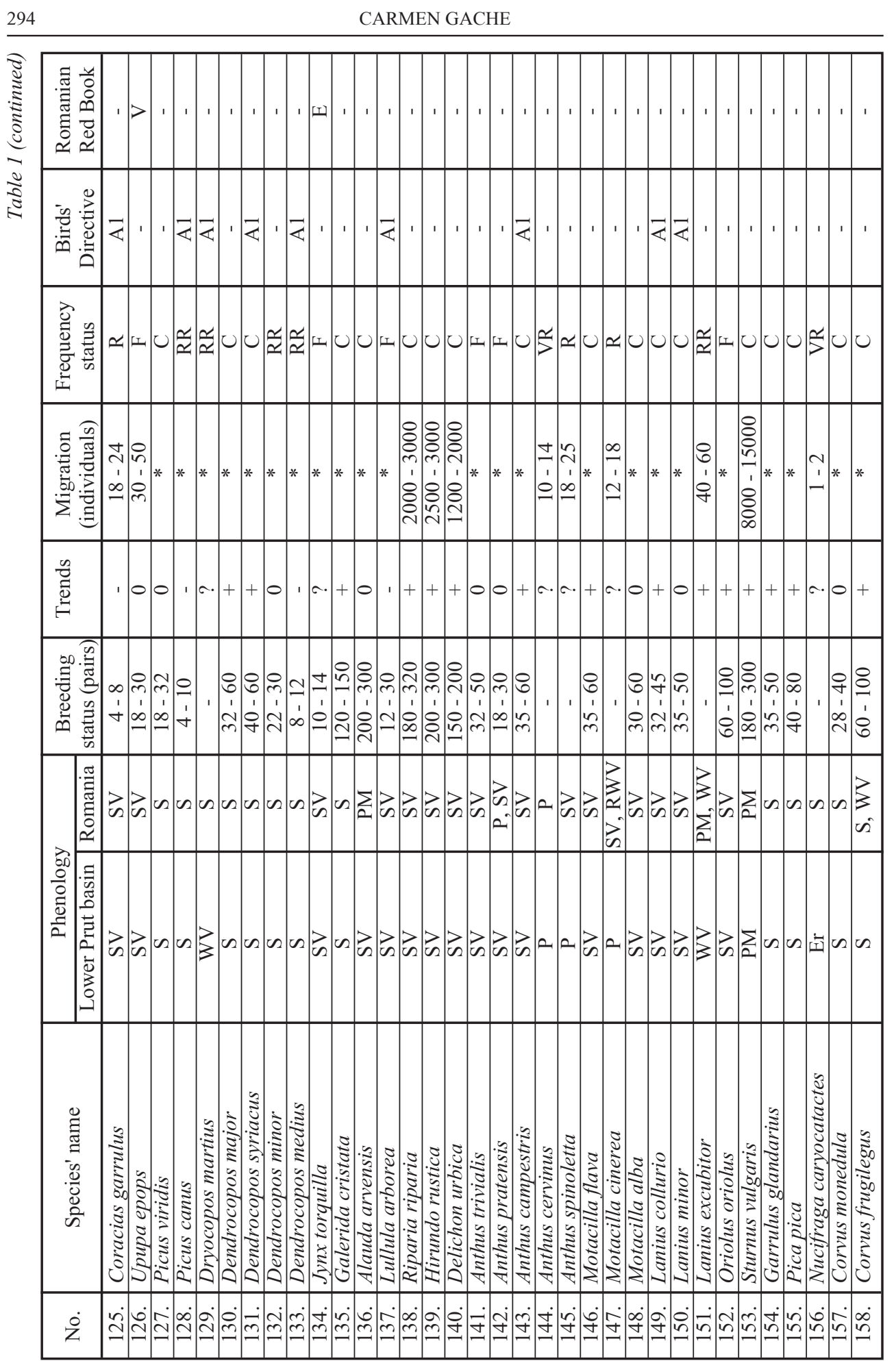




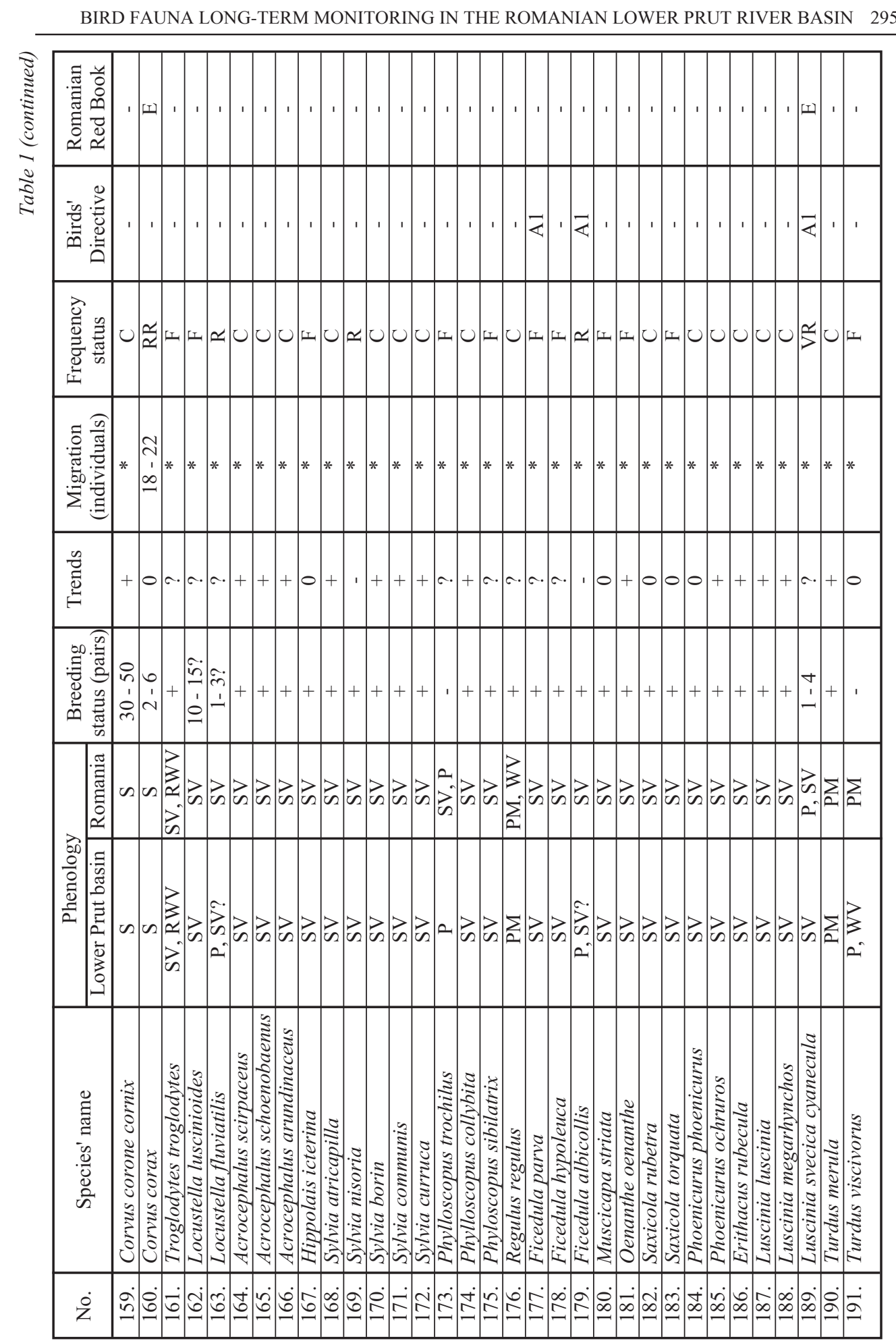




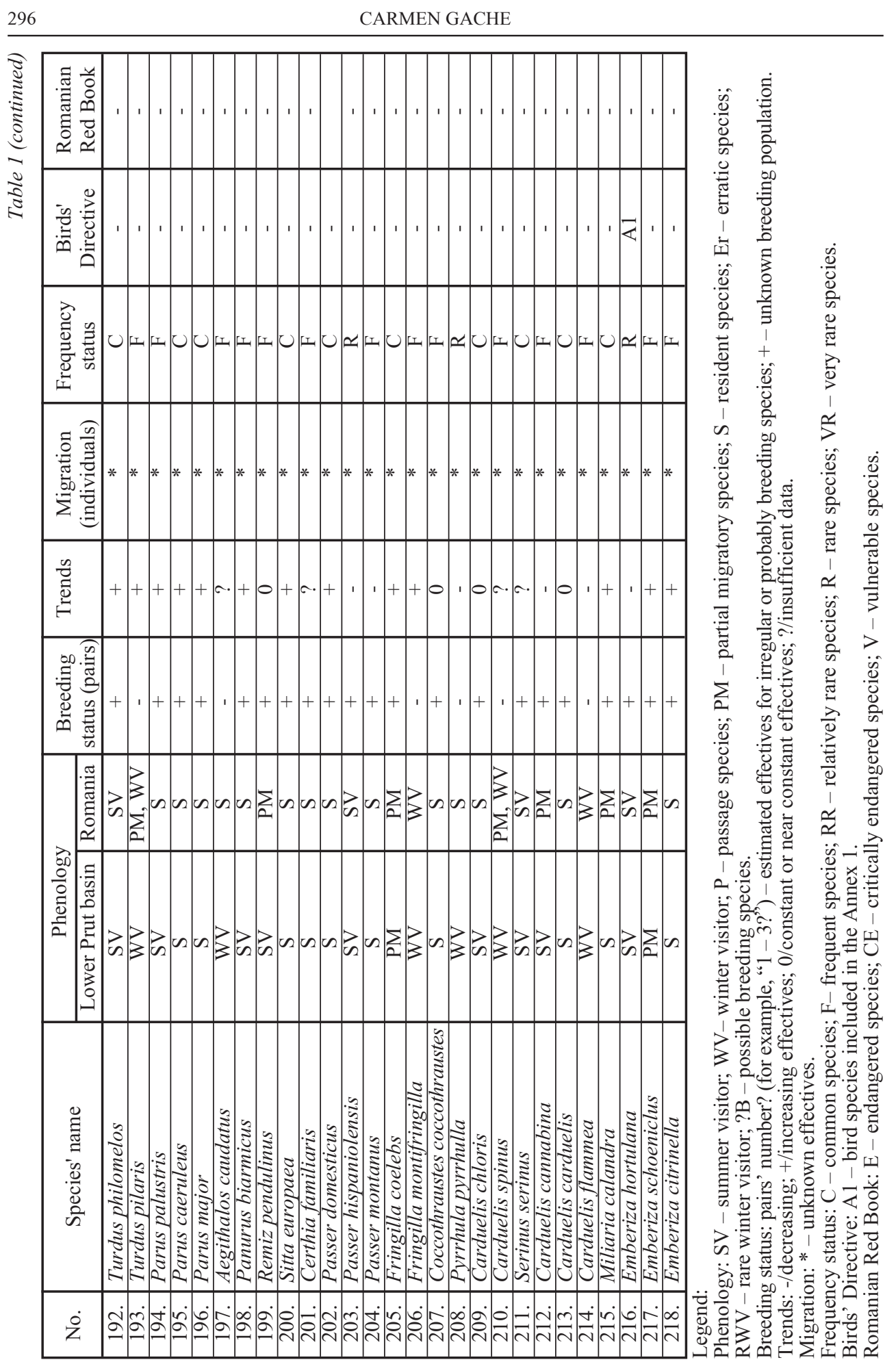


The distribution of the bird species in the area is unequal, the biggest diversity being recorded in the perimeters of the Cârja - Mața - Rădeanu and Vlădești ponds due the high variety of the habitats. The biggest breeding populations were recorded in these perimeters, too and in the inland nearest woodlands (Pogonești, Roșcani). During the years with dry summers, when the small marshes areas are losing the waters and the temporary flooding surfaces become dry, the breeding bird populations are concentrated on the fisheries ponds. But we must mention that the natural swamps Gura Văii, Fălciu, Rânzești, Pochina and some marshes areas between Vlădești pond and Vlășcuța Swamp are very important, too, especially during the passage time.

In the same time, it is necessary to mention the diminishing of the aquatic surfaces including the fishery perimeters through the maintaining dry or transforming in agricultural lands of some former ponds in order to increase the economical benefits. The water's cost and the reduced worker personal in these fisheries determined the administration to keep a partial functional system; for example, in the Vlădești fishery, starting from 2000, the two northern large ponds are dry and were cultivated with maize and sunflower for some years. On the other side, in the Cârja fishery perimeters (there are two fisheries), approximately 45 $50 \%$ from the initially surface is dry and abandoned, while some large ponds were abandoned with not deep waters, permitting the development of a rich aquatic vegetation. During the last five years, in this area the climate oscillated from very dry periods to very high rainfall level, determined flooding phenomenon and the appearance of some new marshes or swampy territories. All this factors influenced the breeding colonies or breeding territories' location and the effectives of the mostly breeding bird species, but also the sites and surface of the feeding perimeters in the Romanian lower part of Prut River basin.

For the majority aquatic and semi-aquatic bird species, we estimated the breeding populations and the trends of their effectives in the investigated area. As we can see in the table 1, these species are very important in the trophic chains of the wetland and aquatic ecosystems through their effectives. Some of them form breeding colonies; we recorded the most important grebes breeding colonies in Cârja - Mața - Rădeanu and Vlădești ponds' territory, presenting a slow but constant negative trends, while the breeding effectives of herons, egrets, Spoonbill (Platalea leucorodia) and Glossy Ibis (Plegadis falcinellus) are concentrated in the perimeters of the Cârja - Mața - Rădeanu ponds and we recorded a slow increasing of their breeding populations for most of species. For example, in 2006, there was certified the first certain breeding of the Glossy Ibis in the Prut River basin, with 35 pairs, while the Spoonbill is breeding species from the middle of ' 90 , but presented a strong negative trend due the high pressure of the local community and, probably, changed the breeding site in North, on the Jijia ponds (Ignat, 2009); now, in the southern sector, Mața - Rădeanu ponds, these two species are breeding, presenting a slow increasing of their effectives. But we assume the possibility that, at least, the Glossy Ibis with other heron species are breeding in the southern part of the investigated area, in the flooding meadow woodlands nearest the confluence of the Prut River with the Danube River, where the access is very difficult and restrictive indeed.

Both species of storks (Ciconia ciconia and C. nigra) present a negative trend in the area, seeing a constant increasing of the unoccupied nests in the villages during the last ten years. 
The tern and the gull colonies were identified in different locations one year to other. For example, at the beginning of our study, one of the most important mixed colonies (grebes and tern species) was located on the western pond in the Brates fishery's perimeter. In the first years of this century, the water costs increased and the fishing production decreased, so the activity of this fishery became nonproductive, so the administration decided to reduce the surface to just some small ponds around the administrative buildings (since 2006). In this way, the birds lost the suitable habitats and were forced to leave this territory. During the years with normal or high level of the rainfalls, we met these species breeding, divided in small colonies, in the natural small swamps and marshes areas, along the flooding protection dam, from Frumușiț to Vlădești villages. When these territories are dry, the birds are going in the perimeters of the fisheries Vlădești and Cârja - Mața Rădeanu.

The geese and duck species are breeding in the dense reed beds, especially, in the nominated two fisheries and in the natural swampy areas situated in the southern sector, recording a constant increasing of the breeding populations. We notice the irregular presence like breeding species of the Shoveler (Anas clypeata) and the constant breeding of one small population of Greylag Goose (Anser anser), concentrated in the quiet sites from the border area (between Vlădești fishery and Vlășcuța Swamp) and on the Mața - Rădeanu ponds.

We have not enough information about the bird species that are breeding in the meadow forests because the access is difficult in most of these ecosystems; on one hand, the forests are far away to the villages, inside the strictly bordering area and we need specific permission to visit the perimeter, sometimes existing the risk (and danger) to met groups of people that try an illegal crossing border, too; on another hand, for large periods, the meadow forests are flooding. For this reason, we can just assume the presence and estimate the effectives of the breeding bird species in this ecosystem, taking point from recorded adult birds during the breeding season and the appearance of the juvenile birds in summer time. We believe that the highest importance for breeding season present the sector of the riverside forest nearest Giurgiulești (closed to the confluence with the Danube) and the sector of the meadow forest from Sivița to Vlădesti villages. In these territories, it is possible the breeding of at least two pairs of Black Storks (Ciconia nigra) and we do not exclude the irregular breeding (at least!) of one pair of Osprey (Pandion haliaetus) - we met the birds during the breeding season on the left side of the basin (on the territory of the scientific reserve "Lower Prut", Republic of Moldova), observing the adults fishing and flying down to the nest, in the meadow forest from the Romanian side of the river (June - July 2005). In these riverside forests, the cormorants (Phalacrocorax sp.) can breed, too - we met both species during the whole breeding season, in August appearing with juveniles. We have certain data on their breeding on the left side of the basin, but we cannot exclude the possibility of the same situation in the trees from the meadow forest on the right side of the valley, probably, together with some egrets and heron species pairs.

During the migration time, the birds' effectives record great values and this is the period when we met the most incidental species in the area. The aquatic species - grebes, cormorants, geese, ducks, gulls and terns - form flocks about hundreds or thousands individuals (Tab. 1).

The Prut River is an important flyway for some species present in the investigated area with very large flocks like Ciconia ciconia, Anser anser, A. 
albifrons, Anas platyrhynchos, A. querquedula, Aythya ferina, A. nyroca, Fulica atra, Vanellus vanellus, Numenius arquata, Limosa limosa, Tringa totanus, Tringa erythropus and Philomachus pugnax. The pelicans (Pelecanus onocrotalus) are searching for food in the fishery perimeter; we recorded flocks about $600-1000$ individuals in Vlădești pond area (July - August), while the Cârja ponds represent the northern limit where we met this species in the Prut River basin, in groups of no more than 180 birds.

In this period, we recorded the biggest effectives for some species that, normally, appear in small groups: the Black Stork (Ciconia nigra) - 54 individuals, on Vlăscuța swamp, 10 October 2002; the Pintail (Anas acuta) - 352 individuals, on the Fălciu Swamps, 17 April 2003; the Shelduck (Tadorna tadorna) - 32 individuals, on the Vlădești ponds, 12 November 2006; the White-tailed Eagle (Haliaeetus albicilla) - 27 September 2007, 2 adults on Șovârca Swamp (acrobat flying for fishing) and one juvenile bird on the Vlădești ponds; the Red Kite (Milvus milvus) - 7 individuals, flying from Cotu Chiului to Vlădești pond direction, 26 September 1993.

The trends of the recorded bird species effectives give an image about the dynamic of bird fauna diversity in the area. As we can see in the figure 2, the mostly bird species present a positive trend in this part of the Prut River basin, but these are not represent more than $42.20 \%$ from the whole bird fauna; for $14.67 \%$ from the identified bird species, we recorded a decreasing of their breeding and migration time effectives and just $24.31 \%$ bird species present constant effectives in this territory. Unfortunately, for almost the fifth part from the recorded bird fauna $(18.80 \%)$, we have not enough data to estimate their effective trends and some of them appear in danger neither at the national level nor in the whole area of distribution.

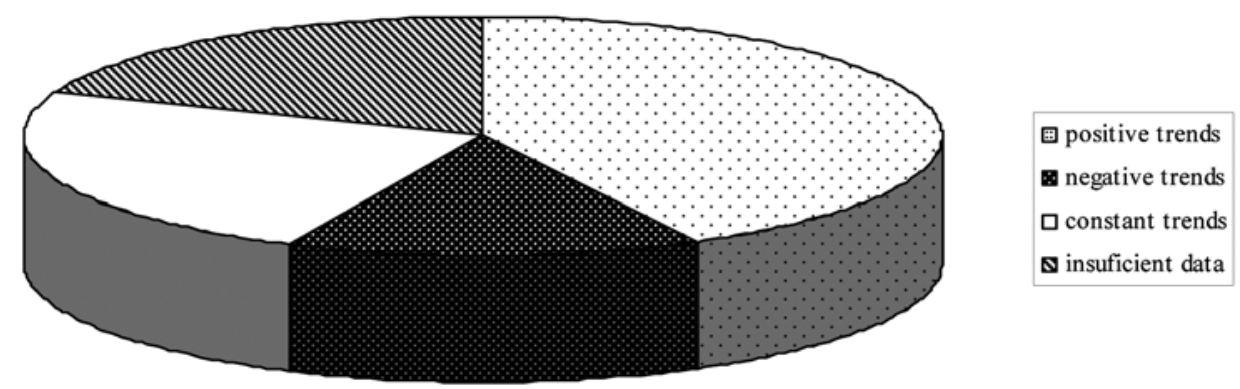

Fig. 2 - The bird species trends in the Lower Prut River basin.

Regarding the frequency status, we recorded 69 common species (present in all observation points with suitable habitats), 75 frequent species (recorded in mostly sites with appropriate habitats), 34 relative rare species and 23 rare species (birds observed just in few places from the investigated area and only in some period of the year), respectively, 17 very rare species (met few times or just in specific observation points during our study).

In the Lower Prut River, we recorded 65 bird species included in the Annex 1 of the Directive 2009/147/EC of the European Parliament and of the Council on the conservation of wild birds, representing important criteria in the biodiversity conservation strategy of the European Union - these bird species shall be subject of 
special conservation measures concerning their habitats in order to ensure their survival and the reproduction in their area of distribution. From these bird species, we recorded 35 certainly breeding species, some of them with important effectives (Botaurus stellaris, Ixobrychus minutus, Ardea purpurea, Platalea leucorodia, Aythya nyroca, Falco vespertinus, Crex crex, Chlidonias hybridus, Lanius minor and Anthus campestris) and another 6 bird species could be at least probably or irregular breeding species in the area, but part of these species have a negative trend, especially, during the last five years.

We notice, also, the presences in the investigated area of 49 bird species from the 56 bird species recorded for the whole Romanian Prut River basin that are included in the Romanian Red Book of Vertebrates (Botnariuc \& Tatole, 2005): 20 vulnerable species, 15 endangered species and 7 critically endangered species (Fig. 3). Some of these species are breeding in the lower part of the Prut River basin with different effectives (Phalacrocorax pygmeus, Nycticorax nycticorax, Ardeolla ralloides, Egretta garzetta, Ardea alba, A. purpurea, Platalea leucorodia, Plegadis falcinellus, Sterna albifrons, etc.), other are seeking food in this territory during the breading season or just in passage (Pelecanus onocrotalus, Tadorna tadorna, Hieraetus pennatus, Circaetus gallicus, Milvus migrans, etc.), while other appears just incidentally (Netta rufina, Numenius tenuirostris, Sterna caspia, etc.).

The human relation with the bird fauna is relatively positive, till now. The fisheries administration accepts the presence of the aquatic and semi-aquatic birds, but for the fish-eating bird species (pelicans and cormorants), they try to find nonaggressive measures to drive away. In the perimeter of the Rădeanu ponds, there existed the intention to use this area like hunting territory, but the change of this territory' status through it including in the "Lower Meadow of Prut River" Natural Park forced the administration abandon this project. As we saw on the $13^{\text {th }}$ September 2009, the hunting games are organised in the northern sector of the ponds (on the territory of Cârja I and Cârja II fisheries) and this have strong influence on the bird fauna's presence. We recorded at least six points of hunting during that day and we recorded just approximately 100 birds there, most of them Coots (Fulica atra) and isolated individuals of Ferruginous Duck (Aythya nyroca), while in the southern part of the ponds (Mața - Rădeanu), there were concentrated the mostly bird groups, including a flock about 360 individuals of Greylag Goose (Anser anser) and three pairs of Mute Swan (Cygnus olor) with juvenile birds.

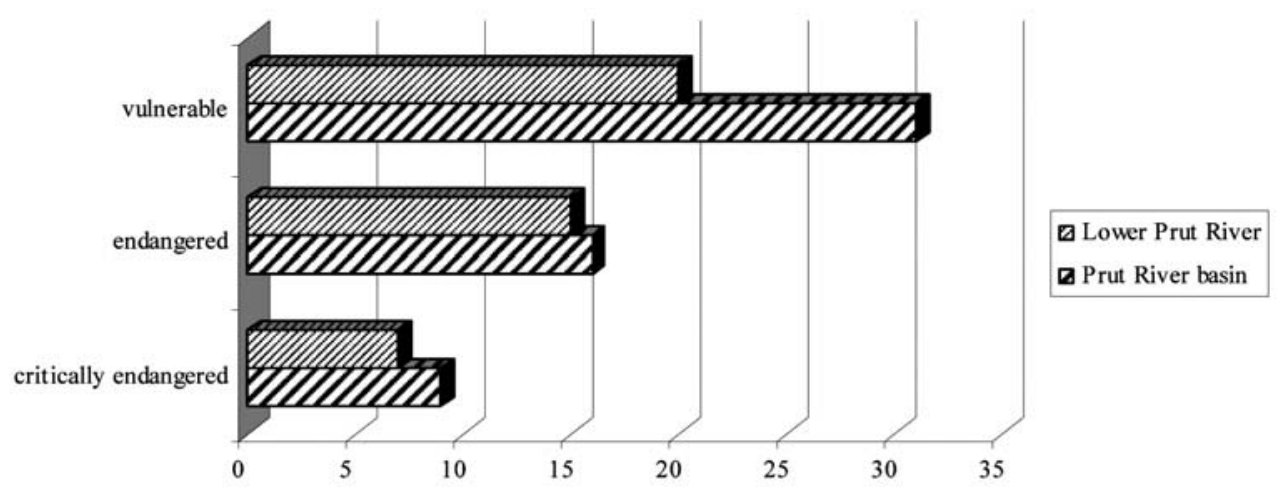

Fig. 3 - The bird species categories included in the Romanian Red Book of Vertebrates recorded in the lower part of the Prut River basin. 
The reed's extraction has not a high importance in this part of the Prut River basin and the local community respecting the seasonal laws nature. But the reed's arson, especially in the spring time, can produce big damages, killing numerous animals and disturbing the breeding season of the birds that are building their nests in perimeter of the reed beds (grebes, herons, egrets, spoonbills, ibises, geese, swans, ducks, etc.).

We recorded the abandonment of some ponds in the existing fisheries that became non-productive in the present economic situation. This has a strong influence on the biodiversity in the area due the lost of wetland surfaces; for example, the Brates fishery reduced its activity and lost more than $80 \%$ of the pond areas, abandoning or transforming its surfaces in agricultural lands. The birds, which used these ponds like breeding (terns, grebes, warblers) and feeding territories (grebes, herons, waders, gulls and terns, etc.) had disappeared from the area. We believe that these birds gone upper on the valley, on the temporary swamps between Giurgiulesti and Vlădești or in the perimeter of Vlădești fishery ponds. At least for some species (Chlidonias sp.), this fact was verified in field (Cazacu, 2007).

As we saw during the last years, one problem for the bird fauna stability is the absence of the waters inside the meadow forests and in the natural swampy or marshes areas. There exist, also, interest to develop projects of ecological restoration of some lost wetlands in the lower part of the Prut River basin, inside the natural park; these can bring the solution for the biodiversity increasing and, also, for the temporary water stocking during the flooding periods.

In the last two - three years, we observed the appearance of numerous windy measuring systems in order to create wind farms in this territory. In a monitoring program done in Vaslui county, we recorded a seriously impact of the pillars with systems of wind parameter measures on the small passerines. We met birds died through the impact with the wires that are fixing the pillars in the ground. These wires are thin and grey, so, seems to be, practically, invisible for the small birds that are flying in the area. We assume that one or more wind farms in this region will represent a high risk for the bird and bat fauna in the area due high importance of the bird migration flyway along the Prut River basin (probably, for bats, too, but there are not any study on this group presence in this region).

\section{Conclusions}

The lower part of Prut River basin still preserves a high biodiversity level, the bird fauna being really rich.

At first side, the breeding bird species diversity and effectives record high values, but for the mostly species the breeding populations have a slowly negative trend in the last years.

During the migration time, this territory is sheltering not only a great bird fauna's diversity but big effectives of aquatic and semi-aquatic bird species, too.

The human pressure is still low in the Romanian sector of the lower Prut River basin, but increased in the left side.

The water level and the diminishing of the aquatic surfaces, including through the collapse of the fisheries represent the greatest impact factor for the bird fauna diversity in the area.

The wind farm development seem to be a major risk factor for the birds in the absence of one rigorous preliminary monitoring study in the future wind farms ${ }^{6}$ perimeters and neighbourhoods. 


\section{ACKNOWLEDGEMENTS}

We want to thank Dr. Dan Munteanu for the critical review and for the improvements of the manuscript.

\section{MONITORIZAREA AVIFAUNEI DIN SECTORUL ROMÂNESC AL BAZINULUI INFERIOR AL PRUTULUI}

\section{REZUMAT}

Prezentăm informatii cu privire la dinamica avifaunei în sectorul românesc al bazinului inferior al Prutului pe parcursul ultimilor 18 ani. Această vale adăpostește o biodiversitate ridicată, fiind foarte bine protejată prin statutul de frontieră, dar și ca urmare a nivelului scăzut al dezvoltării industriale, în ciuda unei creșteri a presiunii umane în ultimii ani. În acest teritoriu, au fost identificate unele specii de păsări clocitoare rare şi foarte rare în România - Platalea leucorodia, Plegadis falcinellus, Limosa limosa, Recurvirostra avosetta, Himantopus himantopus, Luscinia svecica, etc. dar si unele specii protejate pe plan global cum sunt Phalacrocorax pygmeus, Aythya nyroca ori Crex crex. In acest sector al bazinului râului Prut, au fost delimitate trei Arii de Importanță Avifaunistică (A.I.A.), toate fiind incluse în Rețeaua "Natura 2000” din România.

\section{LITERATURE CITED}

BOTNARIUC, N., V. TATOLE (eds), 2005 - Cartea Roșie a Vertebratelor din România [Red Book of the Vertebrates from Romania]. Published by the „Grigore Antipa” National Museum of Natural History and the Romanian Academy. 260 pp. (in Romanian)

CAZACU, M., 2007 - Studiul ecologic și etologic asupra genului Chlidonias (Aves - Ord. Charadriiformes, Familia Sternidae) din bazinul inferior românesc al Prutului (Ecological and behaviour study on the Chlidonias genre in the Romanian Lower Prut River basin). Rezumatul tezei de doctorat, Universitatea „Al. I. Cuza” Iaşi. (in Romanian)

GACHE, C., 2002 - The dynamic of the birds' fauna in the Prut River basin. Romanian Ornithological Society Publications, 15, Risoprint Press, Cluj-Napoca. 210 pp.

IGNAT, A. E., 2009 - Aspecte privind biologia stârcilor, lopătarilor și țigănușilor din zona centrală a bazinului românesc al Prutului (Aspects on the biology of the herons, spoonbills and glossy ibises from the central part of the Romanian Prut River basin). Edit. Universitatea "Al. I. Cuza". 253 pp. (in Romanian)

PAPP, T., C. FÂNTÂNA (eds), 2008 - Important Birds Area in Romania. Romanian Ornithological Society \& Milvus Group's publication, Tg. Mures. 319 pp.

SIBLEY, C. G., J. E. AHLQUIST, 1990 - Phylogeny and classification of birds of the world: a study in molecular evolution. $2^{\text {nd }}$ printing, Yale University Press, New Haven \& London. 976 pp.

*** 2009 - Directive 2009/147/EC of the European Parliament and of the Council on the conservation of wild birds.

*** 2007 - HG no. 1284 regarding the SPA like part of the Romanian Nature 2000 Network.

Received: December 30, 2009

Accepted: September 20, 2010
“Al. I. Cuza” University, Bd. Carol I, 20A, 700505, Iași, Romania

e-mail: cgache@uaic.ro 